\title{
NEW RECORDS IN BRAZIL REVEAL A DISJUNCT DISTRIBUTION FOR CORDIA WEDDELLII (CORDIACEAE)
}

\author{
José Iranildo Miranda de Melo' (iD, Guilherme M. Antar ${ }^{2,3}$ (iD, Luan Pedro da Silva ${ }^{4}$ (iD \\ \& Thaynara de Sousa Silva ${ }^{5}$
}

\begin{abstract}
${ }^{1}$ Departamento de Biologia, Centro de Ciências Biológicas e da Saúde, Universidade Estadual da Paraíba, Rua das Baraúnas 351, Bairro Universitário, 58429-500 Campina Grande, Paraiba, Brazil; tournefort@gmail.com (author for correspondence).

${ }^{2}$ Departamento de Botânica, Instituto de Biociências, Universidade de São Paulo, Rua do Matão 277, 05508-090 São Paulo, São Paulo, Brazil.

${ }^{3}$ Instituto Tecnológico Vale, Rua Boaventura da Silva 955, 66055-090 Belém, Pará, Brazil.

${ }^{4}$ Departamento de Biologia, Centro de Ciências Biológicas e da Saúde, Universidade Estadual da Paraiba, Rua das Baraúnas 351, Bairro Universitário, 58429-500 Campina Grande, Paraiba, Brazil.

${ }^{5}$ Programa de Pós-Graduação em Botânica, Departamento de Biologia, Universidade Federal Rural de Pernambuco, Rua Dom Manoel de Medeiros s/n, Dois Irmãos, 52171-900 Recife, Pernambuco, Brazil.
\end{abstract}

\begin{abstract}
Melo, J. I. M.; G. M. Antar, L. P. Silva \& T. S. Silva. 2021. New records in Brazil reveal a disjunct distribution for Cordia weddellii (Cordiaceae). Darwiniana, nueva serie 9(2): 320-328.

Cordia weddellii, a species of Cordia sect. Cordia (Cordiaceae, Boraginales) endemic to South America is recorded for the first time in Brazil, growing in Cerrado vegetation in Bahia and Tocantins states. A distribution map, photographs, comments on the habitat and phenology, and a preliminary conservation assessment are provided for the species. Additionally, we provide a lectotype for C. weddellii.
\end{abstract}

Keywords. Boraginales; Cerrado; distribution; diversity; Tocantins.

Resumen. Melo, J. I. M.; G. M. Antar, L. P. Silva \& T. S. Silva. 2021. Nuevos registros en Brasil revelan una disyunción de Cordia weddellii (Cordiaceae). Darwiniana, nueva serie 9(2): 320-328.

Cordia weddellii, una especie de Cordia sect. Cordia (Cordiaceae, Boraginales) endémica de Sudamérica fue registrada por primera vez en Brasil, creciendo en la vegetación de Cerrado en los estados de Bahía y Tocantins. Se presentan un mapa de distribución, fotografías, notas sobre ambientes y fenología reproductiva, y una evaluación preliminar del estado de conservación de la especie. Además, se designa lectotipo para C. weddellii.

Palabras clave. Boraginales; Cerrado; distribución; diversidad; Tocantins.

\section{INTRODUCTION}

Cordia L. is the largest genus of Cordiaceae (Boraginales - following the familial classification proposed in BWG (2016)) comprising around 250 species widely distributed in tropical and subtropical regions, with many species restricted to the Neotropics (Miller \& Gottschling, 2007; BWG, 2016). Currently its infrageneric classification comprises six sections: Cordia sect. Cordia L., C. sect. Gerascanthus (P. Browne) G. Don, C. sect. Rhabdocalyx A. DC., 
C. sect. Pilicordia A. DC., C. sect. Superbiflorae Taroda and C. sect. Myxa Endl. (Stapf, 2007; Miller, 2013).

In recent decades, many studies have contributed to the knowledge of the sections of Cordia, such as taxonomic revisions, new species descriptions and local flora treatments (e.g. Miller, 2001; 2013; Stapf, 2007; Melo, 2012, 2015; Melo \& Lyra-Lemos, 2008; Melo et al. 2009, 2018; Vieira et al., 2013, 2015; Guimarães et al., 2016; Melo \& Vieira, 2017; Costa \& Melo, 2019). However, many specimens of Cordia still need revision and/ or are misidentified in herbaria and many areas remain poorly collected. Thus, a better understanding of the diversity of the genus, and its respective sections, as well as the distribution of its species and conservation data requires further and more detailed investigations.

This scenario is especially true for Brazil as it presents remarkably poorly collected areas (BFG, 2015; Oliveira et al., 2017) and where 57 species of Cordia are currently recognized, of which 29 are endemic (Flora do Brasil, 2020). During a floristic survey of the Jalapão region, a poorly collected area inserted in the Cerrado domain (Antar et al., 2018; Antar \& Sano, 2019), a hotspot for conservation (Queiroz et al., 2020), some odd-looking specimens of Cordia were collected. These specimens have serrate or serrulate leaves with an entire base, veins with ferruginous trichomes, cladodromous venation, and a calyx with a mucronulate apex, cymose inflorescences, and foliaceous stigmatic branches. After careful examination, these specimens were recognized as part of Cordia sect. Cordia and a taxon yet unrepresented in the Brazilian territory.

In this work, we present the description of this new record for Brazil, Cordia weddellii I.M. Johnst., a species previously known only from Bolivia and Paraguay, with a morphological description, illustrations, photographs of the species in the field, a preliminary global conservation status assessment, a distribution map and comments on the ecology and its affinities based on morphological features. Additionally, we provide a lectotype for the species.

\section{MATERIAL AND METHODS}

The morphological analyses and species description were based on specimens from the following herbaria: CEN, ESA, HACAM, HUEFS, NY, PY, SPF, UB, and UFG, acronyms according to Thiers (2021). Additionally, the online databases Reflora Virtual Herbarium (Reflora, 2020), GBIF (GBIF.org, 2021), and SpeciesLink (2021) were consulted. Observations and photographic records of the species were carried out in the field in 2013. Morphological terminology for the descriptions follows Radford et al. (1974).

The distribution maps were produced in QGIS (QGIS Development Team, 2020). For distribution purposes, coordinates were gathered from the labels and in the case of their absence, specimens were georeferenced using the locality description. When it was not possible to georeference specimens, the centroid coordinate for the municipality was adopted. The specimens used for the distribution of Cordia weddellii in Bolivia and Paraguay are listed in Appendix 1.

A preliminary conservation status assessment for Cordia weddellii was established only for criterion $\mathrm{B}$, restricted distribution, based on International Union for Conservation Nature criteria (IUCN, 2012) and guidelines (IUCN, 2019). The extent of occurrence (EOO) and area of occupancy (AOO) were evaluated through GeoCAT software (Bachman et al., 2011) using default values.

\section{RESULTS AND DISCUSSION}

\section{Taxonomic Treatment}

Cordia weddellii I.M. Johnst., J. Arnold Arb. 16: 173. 1935. TYPE: Bolivia, Santa Cruz, Chiquitos, $16^{\circ} 46^{\prime} 15$ ” S, 061²7'15” W, September 1845 October 1845, H. A. Weddell 3454 (Lectotype, designated here: P [barcode P00634096]; isotypes: $\mathrm{GH}$ [barcode 00095907, fragment], $\mathrm{P}$ [barcode P00634095]). Figs. 1A-E, 2A-J.

= Corda bordasii Schinini, Bonplandia 5: 101. 1981. TYPE: Paraguay, Nueva Asunción, Ruta Trans-Chaco, Cauce seco, 21 ${ }^{\circ} 30^{\prime} \mathrm{S}, 061^{\circ} 12^{\prime} \mathrm{W}$, 12-III-1979, A. Schinini \& E. Bordas 16533 (holotype: CTES, isotypes: G, MO, NY, SI). 


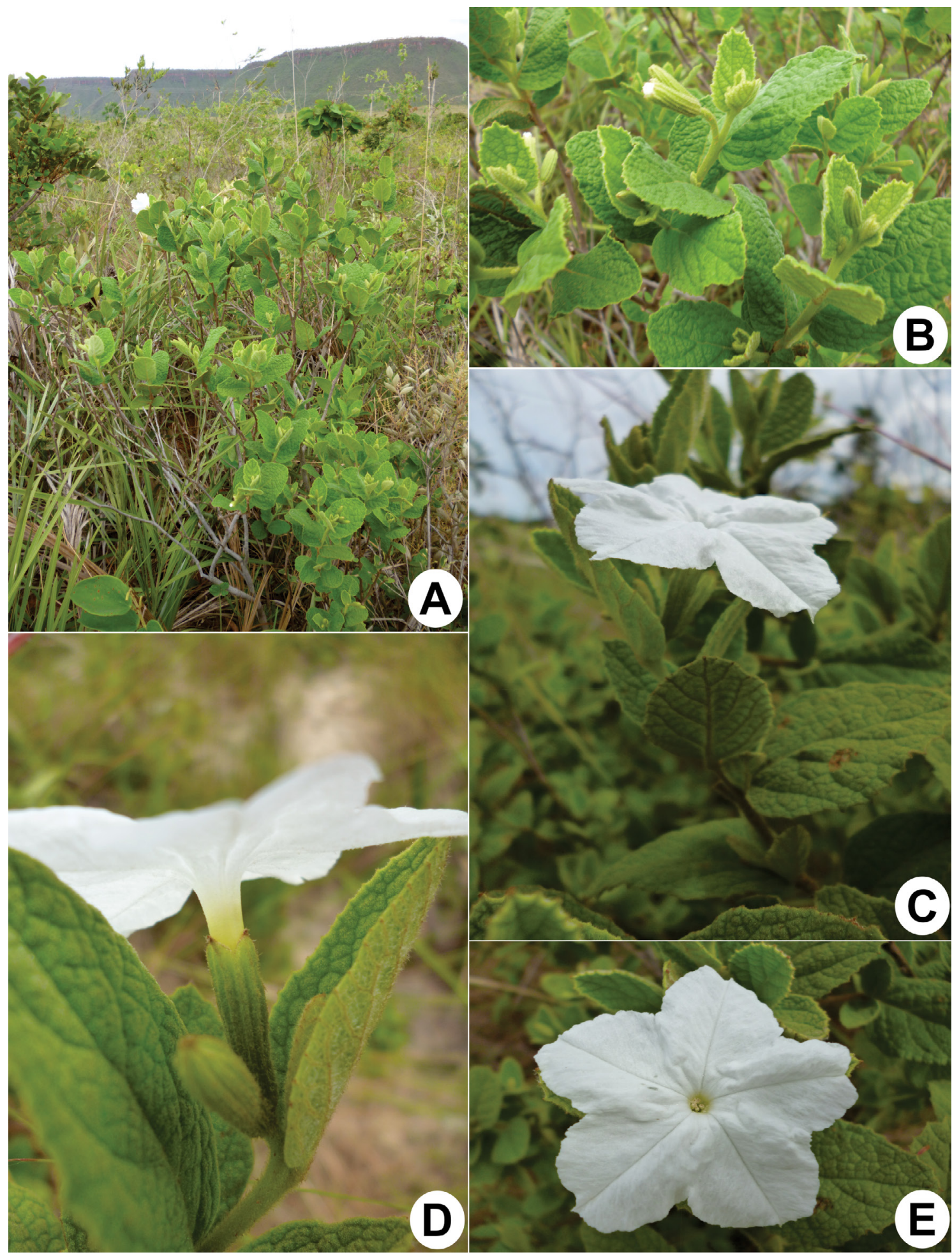

Fig. 1. Cordia weddellii. A, habit. B, flower bud. C, flower in lateral view. D, detail of flower in lateral view. E, flower in frontal view. Photographs by G. M. Antar. Color version at http://www.ojs.darwin.edu.ar/index.php/darwiniana/article/view/964/1232 


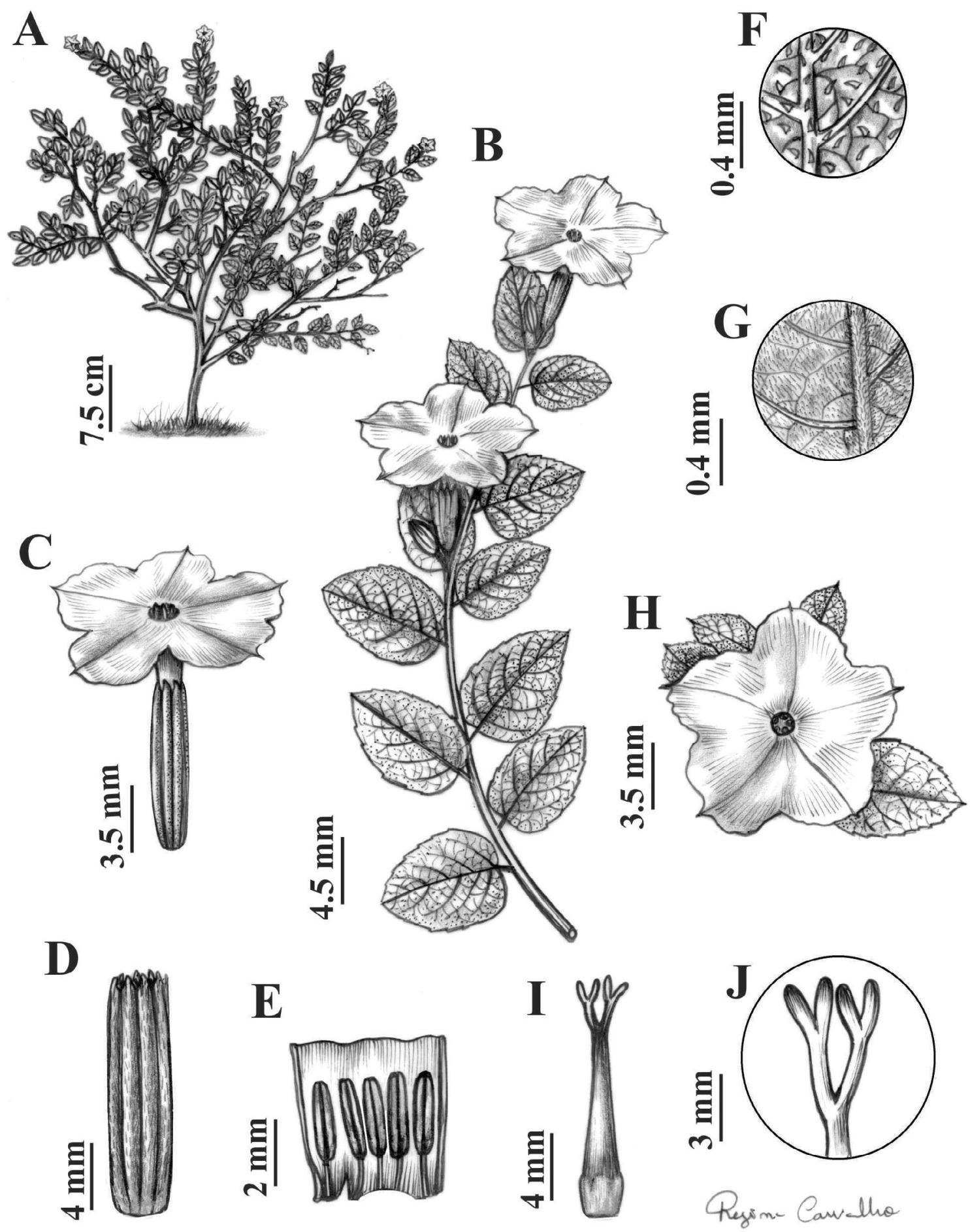

Fig. 2. Cordia weddellii. A, habit. B, flowering branch. C, flower. D, calyx. E, open corolla showing stamens. F, detail showing adaxial surface of leaf blade. $\mathbf{G}$, detail showing abaxial surface of leaf blade. $\mathbf{H}$, flower in frontal view. I, gynoecium. J, stigmatic branches. Line drawings by R. Carvalho, from G.M. Antar \& M. Escaramai 289. 
Shrubs or subshrubs, 0.3-1.2 m tall; branches cylindrical, costate, lenticellate. Leaves alternate, discolorous, petiolate, petiole $0.5-1.5 \mathrm{~cm}$ long, sericeous or hispid; leaf blade 1.7-3.6 $\times$ 1.2-2.6 cm, chartaceous, bullate, ovate; adaxial surface scabrous, abaxial surface tomentose, base cordate or truncate, margins serrate or serrulate with base entire, apex obtuse; venation cladodromous, veins ferruginous. Inflorescences cymose, terminal or internodal. Flowers 1.3-1.5 cm long, monoclinous, dichlamydeous, actinomorphic; subsessile or evidently pedicellate, pedicel ca. $5 \mathrm{~mm}$ long; calyx $1.4 \times 0.4 \mathrm{~cm}$, gamosepalous, tubular-cylindrical, externally sericeous, internally glabrous, apex mucronulate; corolla 1.3-3.0 cm long, hypocrateriform, 5-lobed, rounded, apex acuminate to erose, acuminate in the middle portion, glabrous, resiniferous glands present; stamens 5, epipetalous, homodynamous, filaments ca. $1.2 \mathrm{~mm}$ long, glabrous, anthers rimose, ca. $3 \mathrm{~mm}$ long; ovary ca. $1.8 \mathrm{~mm}$ long, globose, 4-locular, with 1 ovule per locule, presence of white glands in cross section, nectariferous disk present, placentation axillary; style ca. $3 \mathrm{~mm}$ long; stigmatic branches foliaceous, each ca. $0.6 \mathrm{~mm}$ long, erect. Fruits not seen.

Distribution and habitat. Cordia weddellii was previously known only from southwestern South America, in Bolivia and Paraguay. However, in this work it is recorded for the first time in Brazil, presenting a disjunct distribution where it was found in eight localities from Bahia and Tocantins states (Fig. 3), which are part of the Northeast and North regions respectively. The species was found growing in savannah physiognomies (campo sujo and campo cerrado) with dry, sandy soils or rocky savannah with rocky outcrops (cerrado rupestre) at altitudes of 460 to 815 meters, exclusively in areas of the Cerrado phytogeographic domain.

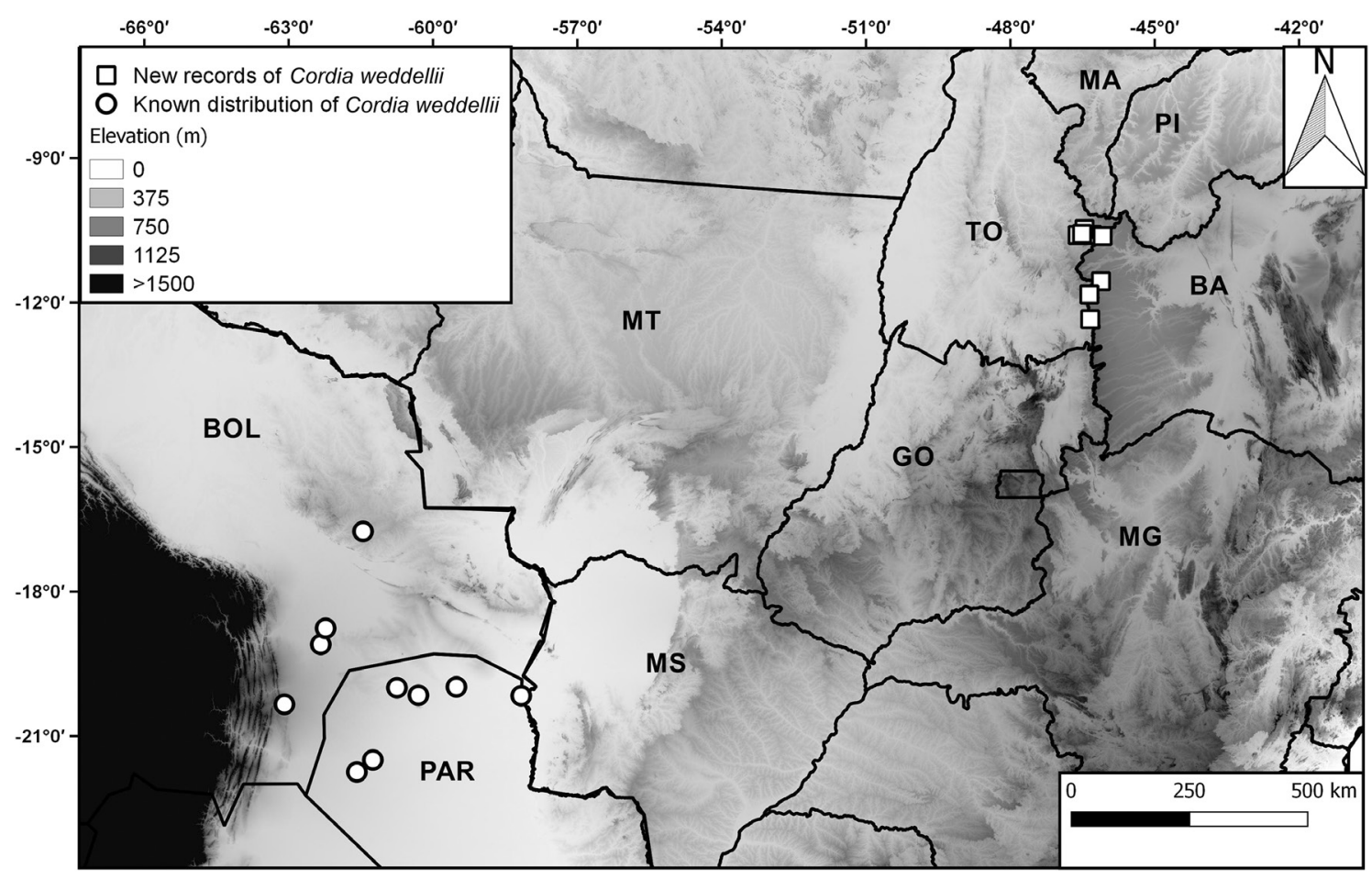

Fig. 3. Distribution map of Cordia weddellii showing the disjunction between previously known collections from Bolivia and Paraguay and new records from Brazil. Abbreviations: Countries and Territories: BOL: Bolivia; PAR: Paraguay. Brazilian States: BA: Bahia; GO: Goiás; MA: Maranhão; MS: Mato Grosso do Sul; MT: Mato Grosso; PI: Piauí; RO: Rondônia; TO: Tocantins. 
Preliminary conservation status. Cordia weddellii is known in Brazil from eight collections, of which five were recorded outside any protected area along the boundaries of Bahia (Northeast region) and Tocantins (North region) states and the other three are restricted to the protected area Parque Estadual do Jalapão, Tocantins state. In Bolivia, it is known until now from three localities, none of them inside Protected Areas; and in Paraguay in five localities, one of them inside the Parque Nacional Defensores del Chaco, a protected area located between the Departments of Alto Paraguay and Boquerón. Although the Extent of Occurrence is high, at $712,600 \mathrm{~km}^{2}$, due to the species disjunct distribution, the Area of Occupancy is reduced, encompassing only $76 \mathrm{~km}^{2}$. Therefore, we categorize the species as endangered EN B2b(ii,iii)c(iv) (IUCN 2012, 2019). Although the species is included in some protected areas, the Cerrado and Chaco domains, in which the species occurs, have been suffering from continuous habitat loss, due to the rapid advance of the agricultural frontier (Morales et al., 2019; Colli et al., 2020). In Brazil, for instance, the region along the borders of Bahia, Tocantins, Piauí and Maranhão is known as MATOPIBA (area comprising parts of Maranhão (MA), Tocantins (TO), Piauí (PI), and Bahia (BA) states), which the Brazilian government regards as a promising region for agricultural development (Antar et al., 2018; Barbosa-Silva \& Antar, 2020). Such development pressures jeopardize the longterm conservation of these northern populations of the species.

Phenology. Recorded flowering in February, May, October, November, and December.

\section{Notes on the species.}

The presence of a distinctly 10-ribbed, tubular-cylindrical calyx, large flowers $(1-4 \mathrm{~cm}$ long), and stamens basally adnate to the corolla tube (Taroda, 1984; Miller, 2013) supports the positioning of this species in Cordia section Cordia. Although Cordia bordasii Schinini is treated as an accepted species in some databases such as the Plants of the World Online (POWO, 2019) and Flora del Cono Sur (Zuloaga \& Anton, 2021), it was recently synonymized under Cordia weddellii in the Catalogue of the Vascular Plants of Bolivia (Jørgensen et al., 2014), which despite not providing a complete justification for this taxonomic decision, is valid according to ICNAFP (Turland et al., 2017). After a careful examination of protologs and specimens, including original material, mostly as part of the preparation of the treatment of Boraginaceae s.l. for the Flora of Paraguay (Melo, pers. comm.), we agree with the synonymization as both species' circumscriptions completely overlap.

Johnston (1935) in the protologue of Cordia weddellii, cites the type as a specimen collected by $H$. A. Weddell numbered 3454 at $\mathrm{P}$ herbarium. However, on checking the material housed at $\mathrm{P}$, two specimens of $H$. A. Weddell 3454 were found. The specimen with barcode P00634096 is the most complete, with handwriting in the label stating that it is the type. For this reason, the material P00634096 is designated here as the lectotype.

During a survey in various Brazilian herbaria, some specimens of Cordia weddellii were identified as belonging to the genus Varronia P. Browne, probably due to its shrubby habit, leaves with serrate or serrulate margins and cymose inflorescences. However, the presence of pedicellate or subsessile flowers (always sessile in Varronia) and the long tubular and conspicuously ribbed calyx (shortly tubular and never ribbed in Varronia) supports its placement in Cordia.

The highly disjunct pattern, separated by ca. 1700 $\mathrm{km}$, called our attention, and our first hypothesis was that the specimens from Brazil corresponded to a new species. However, after a more detailed analysis, we verified that these specimens fit entirely in the concept of Cordia weddellii, without even any noticeable morphological differences from the type populations. Nevertheless, it is intriguing why a species that apparently has no significant ecological preferences presents such a disjunct distribution. The species inhabits savanna formations in Chaco (Paraguay) and Cerrado (Bolivia) domains, and, located between the confirmed occurrences for the species, there is a lot of similar vegetation, mostly in Mato Grosso and Mato Grosso do Sul states.

Although we could not detect any other species with a similar Bolivia/Paraguay - Tocantins/ Bahia states disjunct distribution, other longdistance disjunctions in South America are known. 
Examples are between the Andes and the mountains of southeastern Brazil (e.g., Asplenium castaneum Schltdl. \& Cham., Sylvestre \& Windisch, 2003); between semiarid vegetation along the lower Orinoco River, in the Brazilian semiarid region (Caatinga) and Venezuela (e.g., Eriopidion strictum (Benth.) Harley, Harley \& Pastore, 2012); between the Guyana Highlands and southeastern Brazil (e.g., Asplenium pedicularifolium A. St.-Hil., Sylvestre \& Windisch, 2003); and between Amazonia and the Atlantic Rainforest (e.g., Couratari macrosperma A.C. Sm., Ribeiro et al., 2020).

The drupaceous fruits of Cordia weddellii, which are probably consumed by birds, could explain its wide dispersal. However, this pattern could also be explained by the lack of collections (BFG, 2015), and future expeditions may uncover new populations in Mato Grosso and Mato Grosso do Sul states (Brazilian Central-west region). Furthermore, future phylogeographic studies are desirable to better understand the differences between the disjunct populations and allow for the proposition of well-grounded hypotheses to explain this peculiar distribution pattern.

\section{Specimens examined}

BRAZIL. Bahia. Formosa do Rio Preto, 10³7'12” S, 4604'48” W, 11-XII-2017, O. Neto 881 (UB); ibid, $20 \mathrm{Km}$ da guarita da Faz. Estrondo,

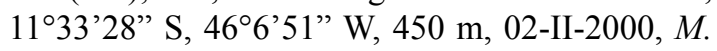
L. Guedes et al. 6792 (HUEFS). Divisa entre Bahia e Tocantins, $11^{\circ} 49^{\prime} 58^{\prime \prime}$ S, 46²1'20” W, 14-I-2007, J. F. B. Pastore et al. 2406 (HUEFS, NYBG, UB). Tocantins. Mateiros, Estrada Rio Nova, $10^{\circ} 36^{\prime} 0^{\prime \prime}$ S, 46³6'0” W, 469 m, 09-V-2001, L. H. Soares e Silva et al. 984 (CEN, UFG); ibid, Parque Estadual do Jalapão, 10³4’31" S, 46³0'29” W, $521 \mathrm{~m}$, 30-X-2013, G. M. Antar \& M. Escaramai 289 (HACAM, SPF); ibid, APA Jalapão, estrada para São Felix do Tocantins, $10^{\circ} 28^{\prime} 26^{\prime \prime}$ S, 4627'22" W, 518 m, 02-XII-2012, M. L. Fonseca et al. 6738 (HUEFS); ibid, ca $23 \mathrm{Km}, 10^{\circ} 35^{\prime} 48^{\prime \prime}$ S, 46 ${ }^{\circ} 17^{\prime} 46^{\prime}$ " W, 603 m, 11-XI-2009, E. Melo 7212 (HUEFS); ibid, Fazenda Alvorada, 01-VI-2008, J. Cordeiro et al. 2845 (MBM). Taguatinga, Serra Geral de Goiás, em direção ao distrito de Luís Eduardo Magalhães, $12^{\circ} 20^{\prime} 50^{\prime}$ ' S, 46 20'17” W, 815 m, 26-I- 2005, J. Paula-Souza et al. 4753 (ESA).

\section{ACKNOWLEDGEMENTS}

We thank Regina Carvalho for preparing the illustrations, Scott V. Heald, for the English revision of the text, and Erimágna Rodrigues for preparing the distribution map. The National Council for Scientific and Technological Development (CNPq) generously provided an undergraduate scholarship to L. Pedro-Silva through the Scientific Initiation Program of the State University of Paraíba-UEPB (Proc. No. 134747/2019-4) as well as a Ph.D. scholarship to T. S. Silva (Proc. No. 141011/ 2017-3) and a Productivity Research Fellowship recently awarded to J. I. M. Melo (Proc. No. 303860/2019-6). Thanks to The Rufford Foundation for the Rufford Small Grant awarded to T. S. Silva (No. 24813-1) and PROPESQ-UEPB grant awarded to J. I. M. Melo (Proc. No. 2.03.00.00-0-370/2017-1). G. M. Antar thanks CAPES, FAPESP (2014/01851-7) and Idea Wild for financial support.

\section{BIBLIOGRAPHY}

Antar, G. M.; M. F. Santos \& P. T. Sano. 2018. Rediscovery and taxonomic reassessment of four angiosperms in the savannas of Jalapão, Central Brazil. Edinburgh Journal of Botany 75(1): 55-71. DOI: https://doi.org/10.1017/ S0960428617000348

Antar, G. M. \& P. T. Sano. 2019. Angiosperms of dry grasslands and savannahs of Jalapão, the largest conserved Cerrado area in Brazil. Rodriguésia 70: 1-9. DOI: https:// doi.org/10.1590/2175-7860201970070

Bachman, S.; J. Moat, A. W. Hill, J. Torre \& B. Scott. 2011. Supporting red list threat assessments with GeoCAT: Geospatial conservation assessment tool. ZooKeys 150: 117-126. DOI: https://doi.org/10.3897/ zookeys. 150.2109

Barbosa-Silva, R. G. \& G. M. Antar. 2020. Description vs deforestation: Couepia brevistaminea (Chrysobalanaceae), a new species on the frontier of agricultural expansion in the Brazilian savanna. Phytotaxa 471(1): 38-46. DOI: https://doi.org/10.11646/phytotaxa.471.1.4

BFG. 2015. Growing knowledge: an overview of Seed Plant diversity in Brazil. Rodriguésia 66(4): 1085-1113. DOI: https://doi.org/10.1590/2175-7860201566411

BWG - Boraginales Working Group. 2016. Familial classification of the Boraginales. Taxon 65(3): 502-522. DOI: https://doi.org/10.12705/653.5 
Colli, G. R.; C. R. Vieira \& J. C. Dianese. 2020. Biodiversity and conservation of the Cerrado: recent advances and old challenges. Biodiversity and Conservation 29: 1465-1475. DOI: https://doi.org/10.1007/s10531-020-01967-x

Costa, F. C. P. \& J. I. M. Melo. 2019. Boraginales (Boraginaceae s.l.) and Lamiales (Lamiaceae and Verbenaceae) in a Conservation Area in the Semiarid Region of Northeastern Brazil. Rodriguésia 70: 1-21. DOI: https://doi.org/10.1590/2175-7860201970009

Flora do Brasil 2020. 2021. Jardim Botânico do Rio de Janeiro. Boraginaceae. Available at: http://floradobrasil.jbrj.gov.br/ reflora/floradobrasil/FB64 [June 2021].

GBIF-Global Biodiversity Information Facility, at https:// www.gbif.org/ [Accessed on 2 June 2021].

Guimarães, E. F.; N. T. Ranga \& J. I. M. Melo. 2016. A new species of Cordia (Cordiaceae) for the state of Minas Gerais, Brazil. Anales del Jardín Botánico de Madrid 73(1): 1-3. DOI: https://doi.org/10.3989/ajbm.2402

Harley, R. M. \& Pastore, J. F. B. 2012. A generic revision and new combinations in the Hyptidinae (Lamiaceae), based on molecular and morphological evidence. Phytotaxa 58(1): 1-55.

IUCN (International Union for the Conservation of Nature and Natural Resources). 2012. IUCN Red List categories and criteria: Version 3.1. Second edition. IUCN, Gland, Switzerland and Cambridge, UK.

IUCN Standards and Petitions Committee. 2019. Guidelines for Using the IUCN Red List Categories and Criteria. Version 14. Prepared by the Standards and Petitions Committee. Downloadable from http://www.iucnredlist. org/documents/RedListGuidelines.pdf

Johnston, I. M. 1935. Studies in the Boraginaceae, XI. New or otherwise noteworthy species. Journal of Arnold Arboretum 16(2): 173-205.

Jørgensen, P. M.; M. H. Nee \& S. G. Beck. 2014. Catalogue of the vascular plants of Bolivia. Monographs in Systematic Botany from the Missouri Botanical Garden 127: 1-1744.

Melo, J. I. M. \& R. P. Lyra-Lemos 2008. Sinopse taxonômica de Boraginaceae sensu lato A. Juss. no Estado de Alagoas, Brasil. Acta Botanica Brasilica 22(3): 701-710. DOI: http://doi.org/10.1590/S0102-33062008000300008

Melo, J. I. M.; C. G. R. Lopes \& E. M. N. Ferraz. 2009. Boraginaceae A. Juss. sensu lato em uma Floresta Estacional de Terras Baixas em Pernambuco, Brasil. Revista Caatinga 22(4): 179-186.

Melo, J. I. M. 2012. Flora do Parque Nacional do Catimbau, Pernambuco, Brasil: Boraginaceae sensu lato. Biotemas 25(4): 109-120. DOI: https://doi.org/10.5007/21757925.2012v25n4p109
Melo, J. I. M. 2015. Synopsis of Boraginaceae sensu lato in the Caatingas of the São Francisco River, northeastern Brazil. Anales del Jardín Botánico de Madrid 72(1): 1-8. DOI: https://doi.org/10.3989/ajbm.2398

Melo, J. I. M. \& D. D. Vieira. 2017. Flora da Reserva Biológica Guaribas, PB, Brasil: Boraginaceae. Hoehnea 44(3): $407-$ 414. DOI: https://doi.org/10.1590/2236-8906-04/2017

Melo, J. I. M.; R. C. Paulino, R. C. Oliveira \& D. D. Vieira. 2018. Flora of Rio Grande do Norte, Brazil: Boraginales. Phytotaxa 357(4): 235-260. DOI: https://doi.org/10.11646/ phytotaxa.357.4.1

Miller, J. S. 2001. New Boraginaceae from tropical America 4: three new species of Cordia from South America. Novon 11(4): 421-428. DOI: https://doi.org/10.2307/3393154

Miller, J. S. \& M. Gottschling. 2007. Generic classification in the Cordiaceae (Boraginales): resurrection of the genus Varronia P.Br. Taxon 56(1): 163-169. DOI: https://doi. org/10.2307/25065747

Miller, J. S. 2013. A revision of Cordia section Gerascanthus (Boraginales: Cordiaceae). Journal of the Botanical Research Institute of Texas 7(1): 55-83.

Morales, M.; L. Oakley, A. L. B. Sartori, V. Y. Mogni, M. Atahuachi, R. O. Vanni, R. H. Fortunato \& D. E. Prado. 2019. Diversity and conservation of legumes in the Gran Chaco and biogeograpical inferences. PLoS ONE 14(8): e0220151. DOI: https://doi.org/10.1371/journal. pone.0220151

Oliveira, U.; B. S. Soares-Filho, A. P. Paglia, A. D. Brescovit, C. J. B. Carvalho, D. P. Silva, D. T. Rezende, F. S. F. Leite, J. A. N. Batista, J. P. P. P. Barbosa, J. R. Stehmann, J. S. Ascher, M. F. Vasconcelos, P. De Marco, P. LowenbergNeto, V. G. Ferro \& A. J. Santos. 2017. Biodiversity conservation gaps in the Brazilian protected areas. Scientific Reports 7: 9141. DOI: https://doi.org/10.1038/ s41598-017-08707-2

POWO. 2019. Plants of the World Online. Facilitated by the Royal Botanic Gardens, Kew. Published on the Internet; http://www.plantsoftheworldonline.org/ [Accessed on 4 June 2021].

Queiroz, A. C. M.; A. M. Rabello, D. L. Braga, G. S. Santiago, L. F. Zurlo, S. M. Philpott \& C. M. Ribas. 2020. Cerrado vegetation types determine how land use impacts ant biodiversity. Biodiversity and Conservation 29: $2017-$ 2034. DOI: https://doi.org/10.1007/s10531-017-1379-8

QGIS Development Team. 2020. A free and open source Geographic information system, in https://qgis.org/en/site/ [Accessed on 3 June 2021].

Radford A. E.; W. C. Dickison, J. R. Massey \& C. R. Bell. 1974. Vascular plant systematics. New York: Harper and Row Publishers. 
Reflora-Plantas do Brasil: Resgate histórico e herbário virtual para o conhecimento e conservação da flora brasileira. Available at: http://reflora.jbrj.gov.br/ [Accessed on 3 June 2021].

Ribeiro, M.; N. P. Smith, F. S. Catenacci \& N. B. Cabello. 2020. Lecythidaceae, in Flora do Brasil 2020. Jardim Botânico do Rio de Janeiro. Available at: http://reflora.jbrj.gov.br/reflora/ floradobrasil/FB8547 [Accessed on 18 May 2021]

SpeciesLink. 2021. Downloadable from http://www.splink.org. br/ [Accessed on 3 June 2021].

Stapf, M. N. S. 2007. Avaliação da classificação infragenérica de Cordia L. (Cordiaceae) e revisão taxonômica de Cordia sect. Pilicordia DC. para o Brasil. Tese de doutorado. Feira de Santana: Universidade Estadual de Feira de Santana.

Sylvestre, L. S. \& P. G. Windisch. 2003. Diversity and Distribution Patterns of Aspleniaceae in Brazil. In: Chandra S. \& Srivastava M. (eds.), Pteridology in the New Millennium. Springer, Dordrecht. DOI: https://doi. org/10.1007/978-94-017-2811-9_8

Taroda, N. 1984. Taxonomic studies on Brazilian species of Cordia L. (Boraginaceae). Ph.D thesis. Saint Andrews: University of St Andrews.
Thiers, B. 2021 [continuously updated]. Index Herbariorum: A global directory of public herbaria and associated staff. New York Botanical Garden's Virtual Herbarium, at http://sweetgum.nybg.org/science/ih/ [Accessed on 2 June 2021].

Turland, N. J.; J. H. Wiersema, A. M. Monto, Y-F. Deng \& L. Zhang, L. 2017. XIX International Botanical Congress: Report of congress action on nomenclature proposals. Taxon 66: 1234-1245. DOI: https://doi.org/10.12705/665.16

Vieira, D. D.; A. S. Conceição, J. I. M. Melo \& M. N. S. Stapf. 2013. A família Boraginaceae sensu lato na APA Serra Branca/Raso da Catarina, Bahia, Brasil. Rodriguésia 64(1): 151-168. DOI: https://doi.org/10.1590/S217578602013000100013

Vieira, D. D.; J. I. M. Melo \& A. S. Conceição. 2015. Boraginales Juss. ex Bercht. \& J. Presl in the Ecoregion Raso da Catarina, Bahia, Brazil. Biota Neotropica 15(3): 1-17. DOI: https:// doi.org/10.1590/1676-0611-BN-2014-0201

Zuloaga, F. O. \& A. M. Anton (directores). 2021. Catálogo del Cono Sur. http://conosur.floraargentina.edu.ar/ [Accessed on 3 June 2021].

Appendix 1. List of additional material examined of Cordia weddellii from Bolivia and Paraguay.

BOLIVIA. Santa Cruz. Cordillera, Santa Cruz, ca. 200 kms. hacia el Sud, Proyecto Abapó Izozog, cerca al rio Grande, 12-III-1981, G. Beck 6423 (E); ibid, bañados del Izozog, trayecto entre Laguna Negra y Estancia Toborochi, 1906' S, 62²0' W, 5-I-1993, I. G. Vargas et al. 1910 (F). Curuyuqui, $50 \mathrm{~km}$ SE of Santa Cruz on Rio Parapeti, $18^{\circ} 45^{\prime} 56^{\prime}$ ' S, 62 $13^{\prime} 59^{\prime}$ W, A. Gentry et al. 75145 (MO). PARAGUAY. Alto Paraguay. Agua Dulce, Parque Nacional Defensores del Chaco, 28-X-1980, M. Vavrek \& E. Enciso 8 (PY); ibid, X.1980, M. Vavrek \& E. Enciso 17 (PY); ibid, X.1980, M. Vavrek \& E. Enciso 25 (PY); ibid, XII.1981, D. Darr 610 (PY); ibid, línea 1, 12 km E. de Agua Dulce, trayecto a Lagerenza, 1959' S, 59³0'50" W, 12-IV-1997, F. Mereles 6536 (MA). Puerto Diana, 5 km de Bahía Negra, 20¹0’ S, 58¹0’ W, I-1976, $P$.

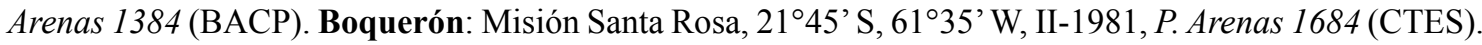
Chaco. Mayor Pedro Lagerenza, 20 S, 6045’ W, 4-IV-1978, A. Schinini \& Bordas 14990 (CTES). 